\title{
Influence of land use/occupation on water quality in the Trussu river valley, Ceará, Brazil ${ }^{1}$
}

\author{
Influência do uso/ocupação da terra na qualidade das águas no vale do rio \\ Trussu, Ceará, Brasil
}

\author{
José Ribeiro de Araújo Neto²*, Eunice Maia de Andrade³, Helba Araújo de Queiroz Palácio², Maria Monaliza de Sales² \\ and Anthony Rafael Soares Maia ${ }^{4}$
}

\begin{abstract}
The growing pressure on water resources has reduced its availability as regards quality. Data was investigated for two different periods, with the aim of evaluating the influence of the use and occupation of space on the temporal dynamics of the quality of surface and groundwater in the perennialised valley of the Trussu River in the State of Ceará, Brazil. The first period was from September 2002 to February 2004 and the second from April 2013 to April 2014. Twenty-two water samples were taken from nine sampling stations, five on the surface and four underground. The same stations were considered, monitoring 12 attributes of water quality for a total of 2,376 analyses. Temporal dynamics were characterised employing a technique of multivariate statistics: hierarchical cluster analysis (HCA). The three groups formed by the surface water were independent of collection time, indicating that there was no significant change at a level of $1 \%$. The main differences between the periods of monitoring were seen in the groundwater, with a reduction in the values of $\mathrm{EC}, \mathrm{Na}^{+}, \mathrm{Cl}^{-}$and $\mathrm{HCO}_{3}^{-}$, and an increase in the concentrations of the $\mathrm{PO}_{4}{ }^{3-}$ and $\mathrm{NO}_{3}^{-}$ions during the second period, forming two distinct groups: group 1 comprising the water collected during the first period, and group 2 the water collected from April 2013 to April 2014. These results reflect changes in the quality of the groundwater due to an increase in agricultural area, and show that the change in land use had a greater impact on the groundwater.
\end{abstract}

Key words: Water contamination. Multivariate analysis. Semi-arid region.

\begin{abstract}
RESUMO - A pressão crescente sobre o recurso água vem reduzindo a sua disponibilidade sobre o aspecto qualitativo. Com o objetivo de avaliar a influência do uso e ocupação do espaço na dinâmica temporal da qualidade das águas superficiais e subterrâneas no vale perenizado do rio Trussu, Ceará, Brasil investigou-se dados em dois períodos distintos. O primeiro período foi de set/2002 a fev/2004 e o segundo de abr/2013 a abr/2014. Foram realizadas 22 coletas de água em 9 estações amostrais, 5 superficiais e 4 subterrâneas. Foram consideradas as mesmas estações, monitorando-se 12 atributos de qualidade de água, totalizando 2.376 análises. A dinâmica temporal foi caracterizada empregando-se a técnica de estatística multivariada, Analise de Agrupamento Hierárquico-AHH. Os três grupos formados para as águas superficiais foram independentes da época de coleta, expressando que não houve alteração significativa ao nível de $1 \%$. As principais diferenças entre os períodos de monitoramento foram observadas nas águas subterrâneas, com redução nos valores de $\mathrm{CE}, \mathrm{Na}^{+}, \mathrm{Cl}^{-}$e $\mathrm{HCO}_{3}^{-e}$ aumento nas concentrações dos íons $\mathrm{PO}_{4}{ }^{3-}$ e $\mathrm{NO}_{3}^{-}$no segundo período, formando dois grupos distintos: o grupo 1 composto pelas águas coletadas no primeiro período e o grupo 2 pelas coletadas de abr/2013 a abr/2014. Tais resultados expressam alteração na qualidade das águas subterrâneas em decorrência do aumento das áreas agrícolas, mostrando que a mudança do uso da terra gerou maiores impactos nas águas subterrâneas.
\end{abstract}

Palavras-chave: Contaminação das águas. Análise multivariada. Semiárido.

\footnotetext{
DOI: $10.5935 / 1806-6690.20170007$

*Autor para correspondência

${ }^{1}$ Recebido para publicação em 26/08/2015; aprovado em 04/04/2016

Pesquisa Financiada pelo Conselho Nacional de Desenvolvimento Científico e Tecnológico - CNPq

${ }^{2}$ Instituto Federal de Educação, Ciência e Tecnologia do Ceará/IFCE, Campus Iguatu, Rodovia Iguatu, Várzea Alegre, Km 05, s/n, Iguatu-CE, Brasil, 63.500-000, juniorifcelabas@gmail.com; helbaraujo23@yahoo.com.br; monnallysa2011@hotmail.com

${ }^{3}$ Departamento de Engenharia Agrícola, Centro de Ciências Agrárias, Universidade Federal do Ceará, Fortaleza-CE, Brasil. eandrade@ufc.br

${ }^{4}$ Companhia de Gestão de Recursos Hídricos do Ceará/COGERH, anthonyrsm@ hotmail.com
} 


\section{INTRODUCTION}

The semi-arid region of Brazil, with an area of $969,589.4 \mathrm{~km}^{2}$ and a population of around 22 million inhabitants, is one of the largest and most densely populated in the world. The shortage of water due to the rainfall regime and the local geology, combined with the occurrence of high rates of evaporation, is responsible for the intermittency of almost the entire hydrographic network. This represents a severe problem for the capture and storage of water in the region. Thousands of reservoirs have therefore been built, whose main purpose is storing water for multiple use, and for maintaining the rivers, especially during the dry periods (ARAÚJO, 2012). This water, subject to high rates of evaporation, turns saline, in some cases reaching salt concentrations that prevent its use in irrigated agriculture (ARAÚJO NETO et al., 2014; MEIRELES; FRISCHKORN; ANDRADE, 2007).

Another source of water, increasingly important for use by man but which has undergone constant degradation, is groundwater (FERNANDES et al., 2010; SALGADO et al., 2011). Groundwater is a strategic reserve, seen today as a competitive factor in the global market. The contamination of these resources by human activity, especially in semi-arid regions, limits water availability or exposes users to water which is not suitable for consumption (ANDRADE et al., 2010).

Monitoring the quantity and quality of surface and groundwater has been carried out by many researchers (ARRAES et al., 2009; LUNA et al., 2013; SANTOS et al., 2014; VAROL et al., 2012) and institutions, and is a powerful tool that enables evaluation of the water supply. The result of this monitoring and data collection is the production of arrays, of proportions which are unsuitable for interpretation due to the large number of variables under study and the continuous monitoring. However, it is possible to establish correlations between measurement variables when monitoring water, with a view to detecting similarities between such variables and new proposals for land use and occupation; in this way, techniques of multivariate statistics, such as hierarchical cluster analysis (HCA), have gained prominence and been applied in several studies (FERNANDES et al., 2010; LOPES et al., 2014; PALÁCIO et al., 2011; SALGADO et al., 2011; WANG et al., 2013).

Another point to be considered is the influence of land use and occupation on water quality, since, depending on the type of land use, there is an increase in surface runoff, with the consequent input of sediment and nutrients directly affecting the quality of the water resources (ARAUJO et al., 2011; DORIGON; STOLBERG; PERDOMO, 2008). On the other hand, areas occupied by forests favour an increase in the rate of flow, as the greater ground cover, stability and infiltration of water into the soil contributes to a reduction in the intensity of the runoff, and results in an improvement in water quality (VANZELA; HERNANDEZ; FRANCO, 2010). With the growing pressure on natural resources, a survey of land use and ground cover plays an important part in analysing urban and rural expansion, as well as in the better planning and organisation of the occupation of any given area (GALHARTE; VILLELA; CRESTANA, 2014).

Based on the above ideas, the aim of this study was to investigate changes in the use and occupation of space in the semi-arid region, and their influence on the temporal dynamics of the quality of surface and groundwater in the perennialised valley of the Trussu River in the town of Iguatu, in the State of Ceará, Brazil.

\section{MATERIAL AND METHODS}

\section{Study area}

The study was carried out in the perennialised stretch of the Trussu River valley $(24 \mathrm{~km})$ produced by the dam of the same name, with a regulated flow which ranges from 0.4 to $4.2 \mathrm{~m}^{3} \mathrm{~s}^{-1}$. The waters are used for human consumption, irrigation and livestock in the region. The study area is located in the basin of the Upper Jaguaribe River (Figure 1), in the south-central region of the State of Ceará.

According to the Köppen classification, the climate of the region is type BSw'h' (hot semi-arid), with an average temperature always greater than $18^{\circ} \mathrm{C}$ in the coldest month. The aridity index, formulated by Thornthwaite (1948), is 0.44, classified as semi-arid. Average potential

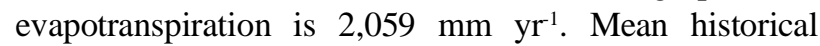
rainfall in the region is $994 \mathrm{~mm}$, with $88 \%$ of the annual rainfall occurring from January to April, and 65\% during March and April (SANTOS et al., 2014), indicating a high concentration of rainfall events over a short period of time. In addition to this concentration, the region is characterised by many hours of sunshine $\left(2,945 \mathrm{~h}_{\text {year }}{ }^{-1}\right)$ and high rates of evaporation.

The area is part of the semi-arid region of backland depressions where the fertile floodplains occur, with a predominance of heavy-textured Fluvic Neosols, surrounded by a topography of gentle slopes with a predominance of Argisols. The natural ground cover along the perennialised stretch of the Trussu River generally shows a high degree of anthropic influence on the vegetation, this being due to extensive grazing, mainly of cattle, combined with the extraction of timber for building fences and for burning. The main use is agriculture, 
including the use of fertilisers on pasture, and animal breeding; there is also the presence of urban centres that contribute with the discharge of untreated domestic sewage. The areas on the banks of the perennialised stretch of the river are extensively used for various crops such as sugarcane, rice, vegetables, maize, beans, cotton, pasture (natural or artificial), and increasingly, the cultivation of irrigated fruit.

\section{Monitoring, sample collection and analysis}

Water sampling campaigns were carried out at 9 stations distributed along the perennialised stretch of the Trussu River valley (Figure 1). Five stations (Ri) are representative of the surface water, and four (Pi) of the groundwater in wells located in areas of alluvial sediment in the perennialised stretch. The collections were made in two separate monitoring periods; during the first period, samples were taken on a monthly basis by Palácio (2004) from September 2002 to February 2004, giving a total of 16 collections for the period, considering that November 2002 and January 2003 were not included due to logistical problems with collection. During the second monitoring period, collections were made every two months from April 2013 to April 2014, to give a total of 6 collections.

The campaigns followed the Standard Methods protocol for the Examination of Water and Wastewater (APHA, 2005). After collection, the bottles were chilled in a cooler $\left(-4{ }^{\circ} \mathrm{C}\right)$. The parameters, analysed and compared between the two monitoring periods, were: $\mathrm{pH}$, electric conductivity (EC), sodium adsorption ratio (SAR), sodium $\left(\mathrm{Na}^{+}\right)$, potassium $\left(\mathrm{K}^{+}\right)$, calcium $\left(\mathrm{Ca}^{+2}\right)$, magnesium $\left(\mathrm{Mg}^{+2}\right)$,

Figure 1 - (a) State of Ceará, Brazil; (b) Upper Jaguaribe River basin, Ceará; (c) Location of the watershed of the Trussu reservoir and of the perennialised stretch in the four municipalities in which it is located; (d) Location of the collection points for surface and groundwater

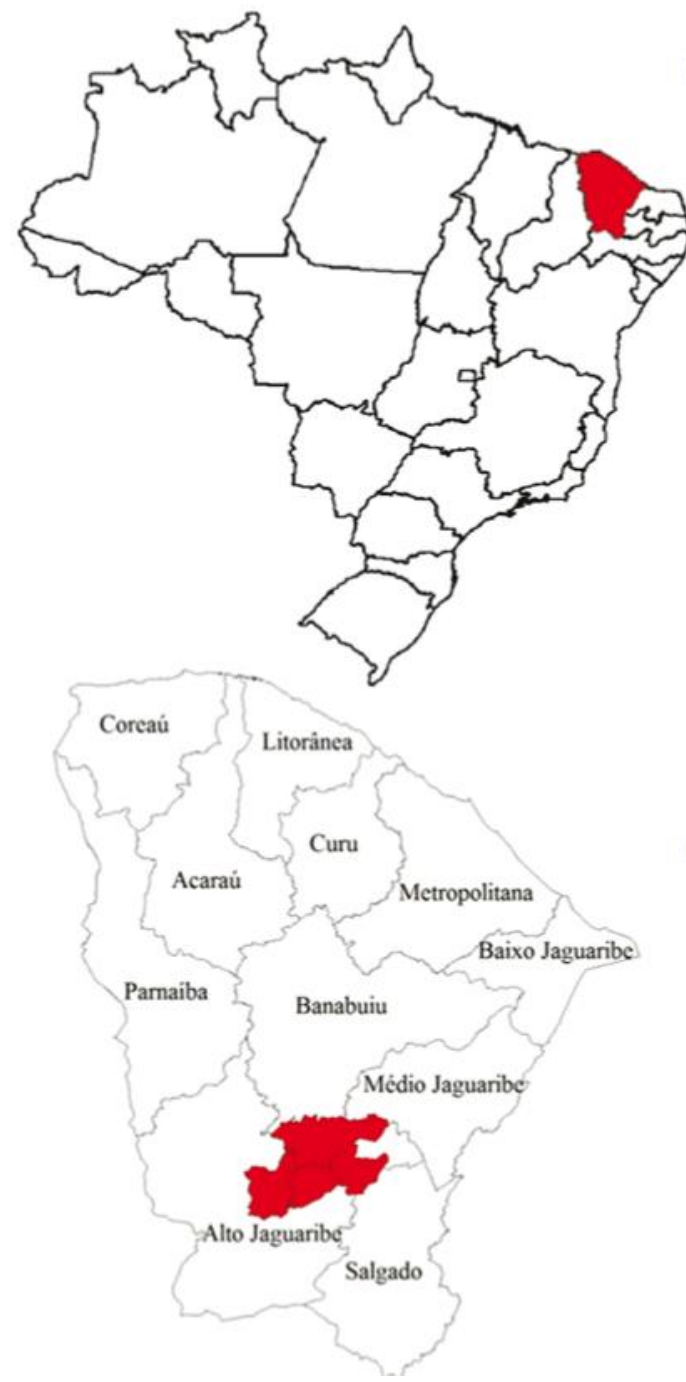

(a)

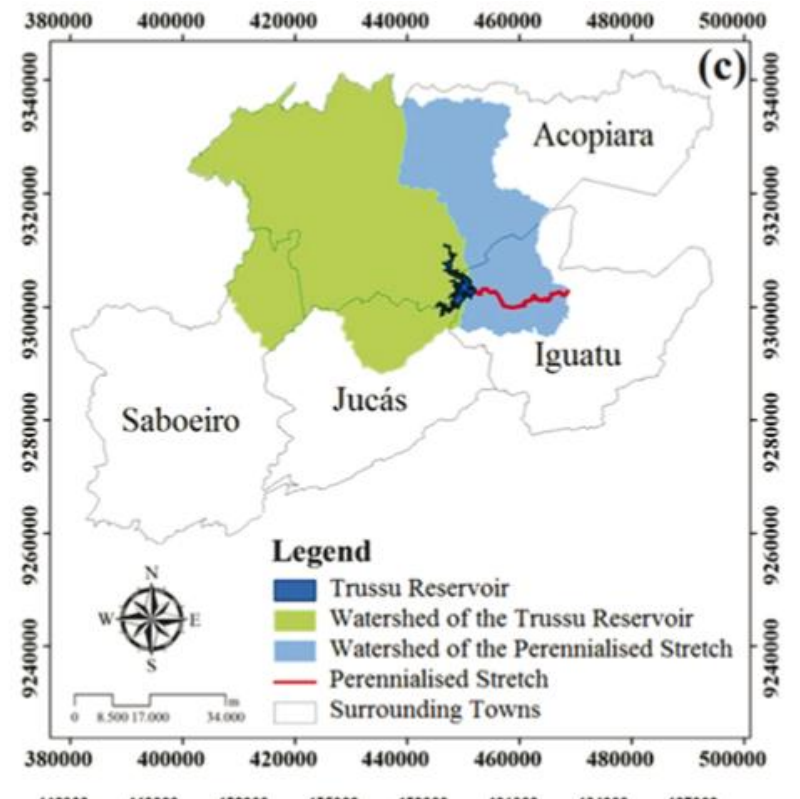

(b)

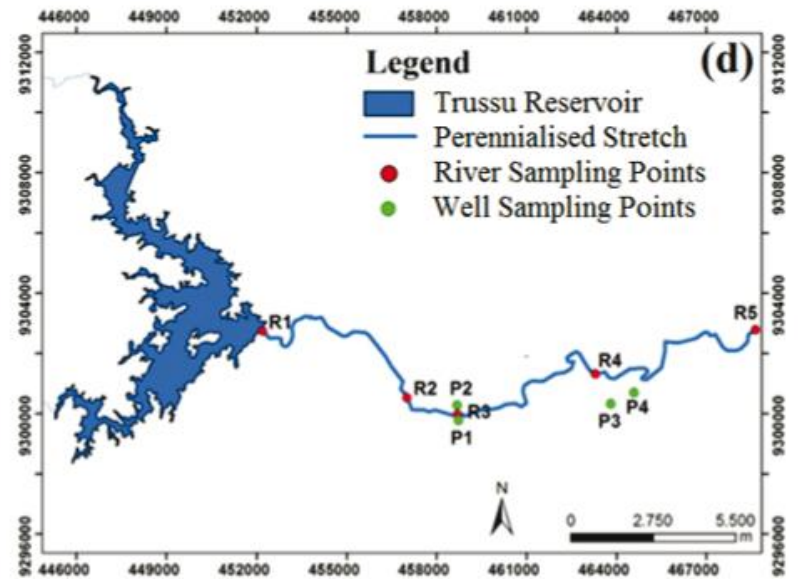


chloride $\left(\mathrm{Cl}^{-}\right)$, bicarbonate $\left(\mathrm{HCO}_{3}^{-}\right)$, sulphate $\left(\mathrm{SO}_{4}{ }^{2-}\right)$, soluble orthophosphate $\left(\mathrm{PO}_{4}^{3-}\right)$ and nitrate $\left(\mathrm{NO}_{3}^{-}\right)$. Twelve attributes of water quality were therefore monitored in 22 campaigns at 9 sampling stations, giving a total of 2,376 analyses.

\section{Survey of land use and occupation}

To classify land use and occupation during the two monitoring periods, images from the Landsat 5 - TM satellite from 26/10/2003 covering the first monitoring period were used, as well as an image from the Landsat 8 - OLI satellite from 19/09/2013 covering the second period. At the processing and image analysis stage, the ArcMap 9.3, ENVI 4.7, ERDAS IMAGINE 9.2, Google Earth 7.1.2 and X-6Scorr software were used. Atmospheric corrections were made of the images, immediately followed by band combination. For the land use and ground cover survey the supervised maximum likelihood classification method was used MAXLIKE. In order to obtain a satisfactory result in the classification of images using this method, the classifier should have prior knowledge of the area to be surveyed, and select a considerable number of pixels for the training samples (COELHO et al., 2014). The classes of usage and ground cover, which were determined in order to understand the dynamics occurring in the watershed of the Trussu reservoir and the perennialised stretch of the Trussu River, were: water, anthropic area, dense scrub and thin scrub.

\section{Statistical data analysis}

Similarity in the quality of the surface and groundwater was estimated using the multivariate analysis technique of hierarchical cluster analysis (HCA), processed with the SPSS 16.0 software. As the classification variables used in this study are real variables and therefore measured on an interval scale, a combination of the squared Euclidean distance to form the similarity matrix and the Ward connection method algorithm (minimum variance method) was adopted. This technique has been applied to water quality data by various researchers (ANDRADE et al., 2010; LOPES et al., 2014; PALÁCIO et al., 2011; WANG et al., 2013; XU et al., 2012). The mean data for each parameter under analysis in the respective groups formed were tested by analysis of means and compared by F-test at a significance level of $1 \%$.

\section{RESULTS AND DISCUSSION}

\section{Changes in land use and occupation}

In the transition between the maps of 2003 and 2013, accelerated dynamics can be seen in the behaviour of the plant cover, with the progressive replacement of areas of dense scrub by areas of thin and anthropic scrub (Figure 2). It can be seen that in 2003 the prevailing classes in the area were of dense scrub $(38.7 \%)$ and thin scrub

Figure 2 - Classification maps of land use and ground cover in the watershed of the Trussu Reservoir and the perennialised stretch of the river for the two time periods under study: (a) 2003 and (b) 2013
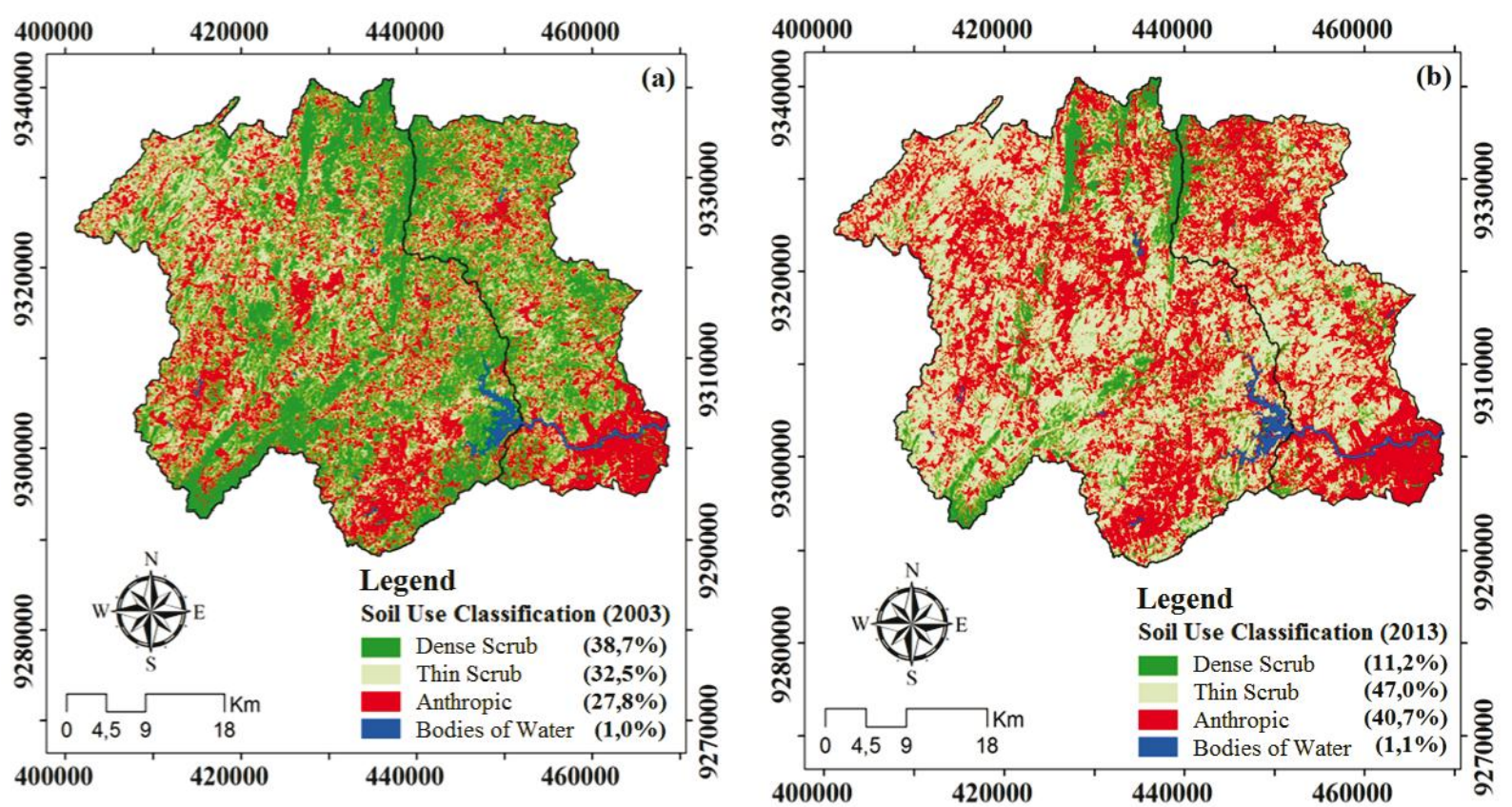
$(32.5 \%)$. In 2013, the anthropic area occupied an area of $40.7 \%$ and together with the thin scrub $(47.0 \%)$ displayed the highest percentages for land use and occupation in the watershed of the Trussu reservoir and the perennialised stretch of the Trussu River. The gradual replacement of the areas of caatinga vegetation by anthropic areas of pasture/agriculture was also seen by Coelho et al. (2014) in a watershed of the semi-arid region of Brazil, the basin of the São Paulo River, which has an area of $47 \mathrm{~km}^{2}$ and is located in the State of Pernambuco, Brazil.

With the start of the perennialised valley of the Trussu River in 2000, a result of the construction of the Trussu reservoir, a greater supply of water was possible. This fact promoted profound changes in the process of land use and occupation. The change in the percentage of ground cover by dense scrub from $38.7 \%$ in 2003 to $11.2 \%$ in 2013 represents a reduction in forested areas for use in such human activities as agriculture, grazing and urbanisation. Researchers like Silva et al. (2014) argue that the practice of cutting down vegetation to produce stakes, coal and firewood for domestic or commercial use, and preparing the area for agriculture, favour a reduction of the caatinga vegetation in the semi-arid region, generating greater pressure on natural resources and causing damage to the environment, especially to the quality of the water in a watershed (GALHARTE; VILLELA; CRESTANA, 2014; SILVA et al., 2014).

\section{Temporal dynamics of surface water quality}

The arrangement similarity of water quality for the two periods under study (September 2002 to February 2004 and April 2013 to April 2014) is described by the dendrogram (Figure 3 ). This shows that the optimal cut-off point of the rescheduled combination distance is between 11.63 and 14.93, since from this value, there is greater distancing of the similarity measure for the formation of further groups, as per a procedure carried out by Lopes et al. (2014), Palácio et al. (2011), Wang et al. (2013) and Xu et al. (2012).

Descriptive statistics for the water quality indicators of each group formed are shown in Table 1. Group 1 was composed of surface water with the greatest salinity levels that were recorded during monitoring. All the samples present in this group are from the first monitoring period, September 2002 to February 2004, with a predominance of nearly all of the samples collected in 2003. The values of the variables in this group were higher than the other groups formed with the HCA, with the exception of the variables $\mathrm{pH}$, $\mathrm{Ca}^{+2}, \mathrm{SO}_{4}^{2-}$ and $\mathrm{NO}_{3}{ }^{-}$.

Group 2 was composed of samples collected between April 2013 and April 2014, together with the
Figure 3 - Homogeneous sampling groups for the surface waters of the perennialised stretch of the Trussu River, Ceará, for the two periods under study

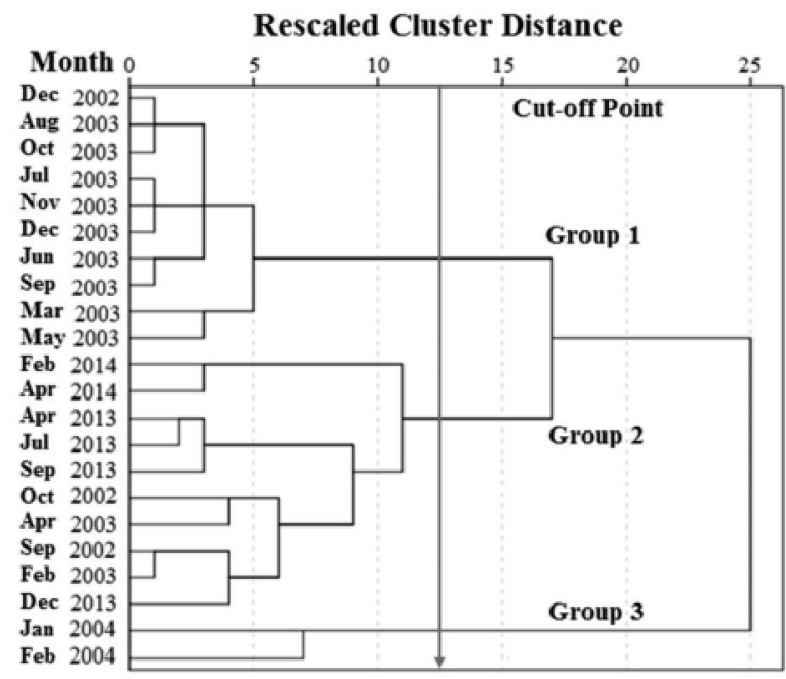

four collections made in September 2002, October 2002, February 2003 and April 2003. The presence in the same group, of samples collected in the two monitoring periods, shows that the surface water of the perennialised section of the Trussu River has not fully differentiated after 10 years of land use and occupation. The impact which occurred due to the increase in anthropic areas in the basin of the reservoir and the perennialised Trussu River (Figure 2) did not affect the surface waters of the perennialised stretch of the river. It can be seen from Figure 3 that after 10 years, concentrations of the indicators being evaluated show no significant differences to those collections made during both monitoring periods, for the same HCA group.

Despite the greater concentrations recorded in group 1, it should be noted that the only indicator of water quality to show a statistically significant difference at a level of $1 \%$, between groups 1 and 2 of the surface waters of the perennialised Trussu River, was $\mathrm{HCO}_{3}^{-}$. Group 2 had the lowest mean values for $\mathrm{HCO}_{3}^{-}=0.86 \mathrm{mmol}_{\mathrm{c}} \mathrm{L}^{-1}$, while group 1 displayed the highest mean values for $\mathrm{HCO}_{3}^{-}=$ $2.15 \mathrm{mmol}_{c} \mathrm{~L}^{-1}$. The greater values for $\mathrm{HCO}_{3}^{-}$in group 1 can be attributed to the samples of this group being taken in 2003, when the Trussu reservoir, responsible for perennialising the river, had a reduced storage capacity due to successive dry years. The greater residence time of the water in the reservoir affected the concentrations of $\mathrm{HCO}_{3}{ }^{-}$in the water during that period.

The higher values for $\mathrm{HCO}_{3}^{-}$in group 1 are worrying for use in irrigation, since water with a concentration of $\mathrm{HCO}_{3}^{-}$greater than $1.5 \mathrm{mmol}_{\mathrm{c}} \mathrm{L}^{-1}$ displays a moderate degree of restriction (AYERS; 
Table 1 - Mean values for the variables under study of similar groups defined by the technique of HCA for surface waters of the perennialised stretch of the Trussu River, Ceará

\begin{tabular}{|c|c|c|c|c|}
\hline \multirow{2}{*}{ Variable } & \multirow{2}{*}{ Statistics } & \multicolumn{3}{|c|}{ Surface Waters of the Perennialised River } \\
\hline & & Group 1 & Group 2 & Group 3 \\
\hline & Mean \pm SD & $7.14 \pm 0.16 \mathrm{a}$ & $7.13 \pm 0.26 \mathrm{a}$ & $7.38 \pm 0.05 \mathrm{a}$ \\
\hline \multirow[t]{3}{*}{$\mathrm{pH}$} & Min & 6.93 & 6.76 & 7.34 \\
\hline & Max & 7.42 & 7.59 & 7.41 \\
\hline & Mean \pm SD & $322.40 \pm 18.18 \mathrm{a}$ & $278.68 \pm 49.65 \mathrm{ab}$ & $233.00 \pm 60.81 b$ \\
\hline \multirow[t]{3}{*}{$\mathrm{EC}\left(\mu \mathrm{S} \mathrm{cm}^{-1}\right)$} & Min & 296.00 & 201.88 & 190.00 \\
\hline & $\operatorname{Max}$ & 356.00 & 324.00 & 276.00 \\
\hline & Mean \pm SD & $1.22 \pm 0.17 \mathrm{a}$ & $1.03 \pm 0.16 \mathrm{a}$ & $1.21 \pm 0.24 \mathrm{a}$ \\
\hline \multirow[t]{3}{*}{ SAR } & Min & 0.98 & 0.76 & 1.04 \\
\hline & Max & 1.57 & 1.25 & 1.38 \\
\hline & Mean \pm SD & $1.41 \pm 0.26 \mathrm{a}$ & $1.16 \pm 0.16 \mathrm{ab}$ & $0.85 \pm 0.09 \mathrm{~b}$ \\
\hline \multirow[t]{3}{*}{$\mathrm{Na}^{+}\left(\mathrm{mmol}_{\mathrm{c}} \mathrm{L}^{-1}\right)$} & Min & 1.12 & 0.93 & 0.79 \\
\hline & Max & 1.96 & 1.34 & 0.91 \\
\hline & Mean \pm SD & $0.28 \pm 0.04 \mathrm{a}$ & $0.26 \pm 0.08 \mathrm{a}$ & $0.24 \pm 0.06 \mathrm{a}$ \\
\hline \multirow[t]{3}{*}{$\mathrm{K}^{+}\left(\mathrm{mmol}_{\mathrm{c}} \mathrm{L}^{-1}\right)$} & Min & 0.20 & 0.06 & 0.20 \\
\hline & Max & 0.37 & 0.35 & 0.28 \\
\hline & Mean \pm SD & $1.61 \pm 0.30 \mathrm{a}$ & $1.73 \pm 0.48 \mathrm{a}$ & $0.61 \pm 0.05 b$ \\
\hline \multirow[t]{3}{*}{$\mathrm{Ca}^{+2}\left(\mathrm{mmol}_{\mathrm{c}} \mathrm{L}^{-1}\right)$} & Min & 1.18 & 1.07 & 0.58 \\
\hline & Max & 1.98 & 2.40 & 0.65 \\
\hline & Mean \pm SD & $0.87 \pm 0.20 \mathrm{a}$ & $0.87 \pm 0.19 \mathrm{a}$ & $0.39 \pm 0.13 b$ \\
\hline \multirow[t]{3}{*}{$\mathrm{Mg}^{+2}\left(\mathrm{mmol}_{\mathrm{c}} \mathrm{L}^{-1}\right)$} & Min & 0.59 & 0.53 & 0.30 \\
\hline & Max & 1.25 & 1.21 & 0.48 \\
\hline & Mean \pm SD & $0.92 \pm 0.11 \mathrm{a}$ & $0.77 \pm 0.41 \mathrm{a}$ & $0.69 \pm 0.01 \mathrm{a}$ \\
\hline \multirow[t]{3}{*}{$\mathrm{Cl}^{-}\left(\mathrm{mmol}_{\mathrm{c}} \mathrm{L}^{-1}\right)$} & Min & 0.79 & 0.24 & 0.69 \\
\hline & $\operatorname{Max}$ & 1.11 & 1.34 & 0.70 \\
\hline & Mean \pm SD & $2.15 \pm 0.10 \mathrm{a}$ & $0.86 \pm 0.31 \mathrm{c}$ & $1.50 \pm 0.22 \mathrm{~b}$ \\
\hline \multirow[t]{3}{*}{$\mathrm{HCO}_{3}^{-}\left(\mathrm{mmol}_{\mathrm{c}} \mathrm{L}^{-1}\right)$} & Min & 1.99 & 0.38 & 1.35 \\
\hline & $\operatorname{Max}$ & 2.33 & 1.35 & 1.66 \\
\hline & Mean \pm SD & $0.08 \pm 0.03 \mathrm{~b}$ & $0.07 \pm 0.02 \mathrm{~b}$ & $0.37 \pm 0.21 \mathrm{a}$ \\
\hline \multirow[t]{3}{*}{$\mathrm{SO}_{4}^{2-}\left(\mathrm{mmol}_{\mathrm{c}} \mathrm{L}^{-1}\right)$} & Min & 0.04 & 0.05 & 0.22 \\
\hline & Max & 0.14 & 0.12 & 0.51 \\
\hline & Mean \pm SD & $0.32 \pm 0.25 \mathrm{a}$ & $0.60 \pm 0.53 \mathrm{a}$ & $0.51 \pm 0.39 \mathrm{a}$ \\
\hline \multirow[t]{3}{*}{$\mathrm{PO}_{4}^{3-}\left(\mathrm{mg} \mathrm{L}^{-1}\right)$} & Min & 0.00 & 0.19 & 0.23 \\
\hline & Max & 0.86 & 1.55 & 0.78 \\
\hline & Mean \pm SD & $0.17 \pm 0.12 b$ & $0.28 \pm 0.13 b$ & $2.10 \pm 1.72 \mathrm{a}$ \\
\hline \multirow[t]{2}{*}{$\mathrm{NO}_{3}^{-}\left(\mathrm{mg} \mathrm{L}^{-1}\right)$} & Min & 0.00 & 0.18 & 0.88 \\
\hline & Max & 0.36 & 0.61 & 3,32 \\
\hline
\end{tabular}

*Mean values followed by different lowercase letters in a column differ by F-test at a level of $1 \%$ 
WESTCOT, 1999). The problem with respect to bicarbonates in irrigation water is that part of the bicarbonate precipitates as calcium and magnesium carbonate, removing these ions from the soil water and increasing the relative proportion of sodium. This process increases the risk of sodicity, as the solubility of sodium carbonate is greater than that of calcium and magnesium carbonate. The presence of surface water presenting moderate restrictions on irrigation due to $\mathrm{HCO}_{3}^{-}$was also seen in the semi-arid region of Ceará, in the Curu, Upper Jaguaribe and Metropolitana basins (ARAUJO NETO et al., 2014; ARRAES et al., 2009; BARROSO et al., 2011).

The determinate attributes in the formation of group 3 for the surface waters were $\mathrm{Ca}^{+2}, \mathrm{Mg}^{+2}, \mathrm{HCO}_{3}$, $\mathrm{SO}_{4}^{2-}$ and $\mathrm{NO}_{3}^{-}$(Table 1); these differed statistically at a level of $1 \%$ from the other groups. The group is characterised by having the smallest mean values for the indicators $\mathrm{EC}=233 \mu \mathrm{S} \mathrm{cm}^{-1} \mathrm{Na}^{+}=0.85, \mathrm{~K}^{+}=0.24$, $\mathrm{Ca}^{+2}=0.61, \mathrm{Mg}^{+2}=0.39$ and $\mathrm{Cl}^{-}=0.69$ in mol $\mathrm{L}^{-1}$, however, it displayed the highest values for the anions $\mathrm{SO}_{4}{ }^{2-}$ and $\mathrm{NO}_{3}^{-}$, of $0,37 \mathrm{mmol}_{\mathrm{c}} \mathrm{L}^{-1}$ and $2.10 \mathrm{mg} \mathrm{L}^{-1}$ respectively, representing an increase of these elements. This is a group formed by two collections, made in
January and February of 2004. These months had a respective rainfall of 420 and $238 \mathrm{~mm}$, a percentage that was higher than the mean for each month by $180 \%$ for January and $45 \%$ for February (Figure 4 ). The high rainfall promoted the dilution of soluble salts and the dragging of nitrates and sulphates.

Heavy rains usually promote entrainment of materials from the topsoil as the end product of the erosion process, especially when the native vegetation has been degraded by agriculture (GALHARTE; VILLELA; CRESTANA, 2014). Despite such entrainment, the concentrations of $\mathrm{NO}_{3}^{-}$in group 3 are of no concern, as the levels are below the standard for potability of $10 \mathrm{mg} \mathrm{L}^{-1}$ established by Ordinance $518 / 2004$ and modified by Ordinance 2,914/2011, both from the Ministry of Health, which regulates procedures for the control and monitoring of water quality for human consumption and standards of potability. The low concentrations of $\mathrm{NO}_{3}^{-}$in the surface waters of the perennialised Trussu River $\left(<3.5 \mathrm{mg} \mathrm{L}^{-1}\right)$ showed similarities to concentrations found in surface water from other parts of the world, such as the Songhua River in China (WANG et al., 2013) and reservoirs in Turkey (VAROL et al., 2012).

Figure 4 - Monthly rainfall for the two monitoring periods: first period, September 2002 to February 2004 and second period, April 2013 to April 2014. Weather station: Iguatu

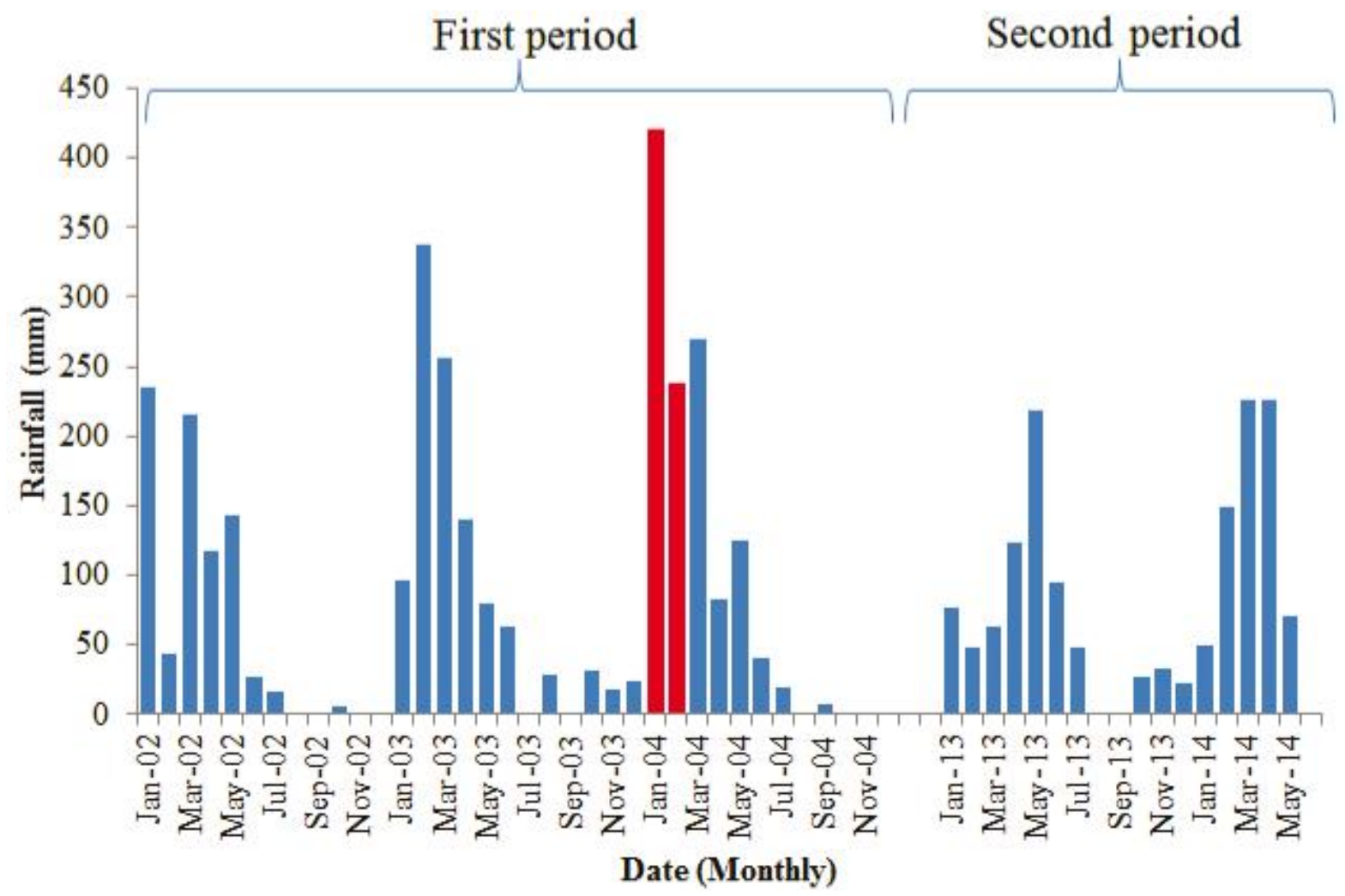




\section{Temporal dynamics of groundwater quality}

The quality of the groundwater in the Trussu Valley is grouped into two classes, with high internal similarity in each group (Figure 5). The dendrogram shows that the optimal cut-off point of the rescheduled combination distance is between 5.21 and 7.22. A value of 6.5 was chosen for the distance, as proposed by Salgado et al. (2011).

Figure 5 - Homogeneous sampling groups for groundwater in wells located along the banks of the perennialised stretch of the Trussu River, Ceará, for the two periods under study

\begin{tabular}{|c|c|c|c|c|}
\hline \multirow{2}{*}{ Month } & \multicolumn{3}{|c|}{ Rescaled Cluster Distance } & \multirow[b]{2}{*}{25} \\
\hline & 5 & $10 \quad 15$ & 20 & \\
\hline $\begin{array}{ll}\text { Jun } & 2003 \\
\text { Aug } & 2003\end{array}$ & & Cut-off Point & & \\
\hline Sep 2002 & & & & \\
\hline Mar 2003 & & & & \\
\hline Apr 2003 & & & & \\
\hline Oct 2002 & & & & \\
\hline Fev 2003 & & Group 1 & & \\
\hline Oct 2003 & & & & \\
\hline Jul 2003 & & & & \\
\hline Dec 2002 & & & & \\
\hline Dec 2003 & & & & \\
\hline $\begin{array}{l}\text { May } 2003 \\
\text { Nov } 2003\end{array}$ & & & & \\
\hline $\begin{array}{l}\text { Nov } 2003 \\
\text { Jan } 2004\end{array}$ & & & & \\
\hline $\begin{array}{l}\text { Jan } 2004 \\
\text { Feb } 2004\end{array}$ & & & & \\
\hline Sep 2013 & & & & \\
\hline Apr 2014 & & & & \\
\hline Jul 2013 & & Groun ? & & \\
\hline Feb 2014 & & & & \\
\hline Apr 2013 & & & & \\
\hline Dec 2013 & & & & \\
\hline
\end{tabular}

Group 1 was composed of the water collected from September 2002 to February 2004, while group 2 comprised all the water sampled from April 2013 to April 2014. This fact shows a dissimilarity in water quality between the two monitoring periods. Most of the attributes of water quality, except $\mathrm{pH}$ and $\mathrm{Mg}^{+2}$, differed statistically at a level of $1 \%$ between groups (Table 2 ).

Group 1 displayed greater values for salinity, with a mean value of $\mathrm{EC}=1,234.84 \mu \mathrm{S} \mathrm{cm}^{-1}$, well above the value of $\mathrm{EC}=761.25 \mu \mathrm{S} \mathrm{cm} \mathrm{cm}^{-1}$ of group 2. Salinity, as a major factor in the formation of two groups in groundwater from the Salgado Basin in Ceará, was also seen by Salgado et al. (2011). Only four attributes of water quality, $\mathrm{K}^{+}, \mathrm{Ca}^{+2}, \mathrm{PO}_{4}{ }^{3-}$ and $\mathrm{NO}_{3}^{-}$, had concentrations in group 1 lower than in group 2.

In group 1 , the ions $\mathrm{Na}^{+}, \mathrm{Cl}^{-}$and $\mathrm{HCO}_{3}^{-}$displayed average values of $8.73,6.95$ and $3.36 \mathrm{mmol}_{\mathrm{c}} \mathrm{L}^{-1}$ respectively, higher than the limits established for use in irrigation, with a moderate to severe risk of toxicity to plants (AYERS, WESTCOT, 1999). High to severe concentrations of $\mathrm{Na}^{+}$ and $\mathrm{Cl}^{-}$were also found by Andrade et al. (2010) applying HCA to groundwater from the Lower Acaraú irrigated perimeter in Ceará, and by Fernandes et al. (2010) in wells in the Acaraú basin in Ceará. Despite higher levels of salinity in the first monitoring period (group 1), the $\mathrm{Ca}^{+2}$ ion displayed values for this group ranging from 1.32 to $2.59 \mathrm{mmol}_{\mathrm{c}} \mathrm{L}^{-1}$, with a mean of $2.02 \mathrm{mmol}_{\mathrm{c}} \mathrm{L}^{-1}$, while the $\mathrm{Mg}^{+2}$ ion displayed concentrations that ranged from 0.71 to $3.53 \mathrm{mmol} \mathrm{L}^{-1}$, with a mean of $2.08 \mathrm{mmol} \mathrm{L}^{-1}$. These values are always below the $5 \mathrm{mmol}_{\mathrm{c}} \mathrm{L}^{-1}$ limit for $\mathrm{Ca}^{+2}+$ $\mathrm{Mg}^{+2}$ established by Ayers and Westcot (1999).

Group 2 presented, as a determinant factor for its formation, the lowest mean values for the indicators of groundwater quality analysed in this study. However, the $\mathrm{PO}_{4}^{3-}$ and $\mathrm{NO}_{3}{ }^{-}$ions showed significant differences at a level of $1 \%$ between the two periods (Table 2). The values for $\mathrm{EC}, \mathrm{Na}^{+}, \mathrm{Cl}^{-}$and $\mathrm{HCO}_{3}^{-}$were significantly lower in the second monitoring period, yet the $\mathrm{PO}_{4}^{3-}$ and $\mathrm{NO}_{3}$ - ions showed an increase of over $1000 \%$ for $\mathrm{PO}_{4}^{3-}$ and $500 \%$ for $\mathrm{NO}_{3}^{-}$. The influence of nutrient concentrations in the water, mainly nitrates and phosphorus, are defined in the literature as indicators of agricultural activity (LOPES et al., 2014; LUNA et al., 2013).

According to data from the Company for Water Resources of the State of Ceará (COGERH), from April 2002 to April 2004 only 2 irrigators were authorised to use water from the perennialised Trussu River valley for irrigation. Whereas between 2005 and 2012, more than 30 irrigators received authorisation. The impact on groundwater, which occurred due to the increase in irrigated agriculture, was also seen in other areas of the semi-arid region (FERNANDES et al., 2010; LUNA et al., 2013; SALGADO et al., 2011).

The higher level of $\mathrm{PO}_{4}^{3-}$ and $\mathrm{NO}_{3}$ - ions during the second monitoring period may be a result of increased leaching of the waste produced by the irrigated agriculture employed in the Trussu Valley over the last ten years. According to the changes in land use and occupation which took place between the 2003 and 2013, the area experienced an accelerated process of replacement of the class of dense scrub for areas with anthropic land used for agriculture, grazing and urbanisation. In 2003, 71.2\% of the area of the basin was occupied by plant cover, comprising both dense and thin scrub, and only $27.8 \%$ of the area was classified as anthropic (Figure 2). By 2013, ten years later, the anthropic area occupied $40.7 \%$, and the area occupied by dense scrub was drastically reduced from $38.7 \%$ to $11.2 \%$. Some researchers demonstrate the positive correlation that exists between anthropic pressure and a decrease in water quality, such as Araújo et al. (2011), who, when studying nitrate contamination of the Barreiras aquifer in the Middle Guama region of the State of Pará, attributed the use of nitrogen fertilizers in agricultural areas 
Table 2 - Mean values for the variables under study of similar groups defined by the technique of HCA for groundwater of the perennialised stretch of the Trussu River, Ceará

\begin{tabular}{|c|c|c|c|}
\hline \multirow{2}{*}{ Variable } & \multirow{2}{*}{ Statistics } & \multicolumn{2}{|c|}{ Groundwater } \\
\hline & & Group 1 & Group 2 \\
\hline \multirow{3}{*}{$\mathrm{pH}$} & Mean \pm SD & $7.10 \pm 0.33 \mathrm{a}$ & $6.95 \pm 0.12 \mathrm{a}$ \\
\hline & Min & 6.79 & 6.80 \\
\hline & Max & 8.06 & 7.13 \\
\hline \multirow{3}{*}{$\mathrm{EC}\left(\mu \mathrm{S} \mathrm{cm}{ }^{-1}\right)$} & Mean \pm SD & $1234.84 \pm 77.02 \mathrm{a}$ & $761.25 \pm 169.57 b$ \\
\hline & Min & 1085.00 & 579.30 \\
\hline & Max & 1372.50 & 1012.75 \\
\hline \multirow{3}{*}{ SAR } & Mean \pm SD & $5.56 \pm 1.21 \mathrm{a}$ & $3.97 \pm 1.12 b$ \\
\hline & Min & 3.12 & 2.40 \\
\hline & Max & 7.15 & 5.50 \\
\hline \multirow{3}{*}{$\mathrm{Na}^{+}\left(\mathrm{mmol}_{\mathrm{c}} \mathrm{L}^{-1}\right)$} & Mean \pm SD & $8.73 \pm 1.83 \mathrm{a}$ & $6.33 \pm 1.97 b$ \\
\hline & Min & 5.21 & 3.70 \\
\hline & Max & 11.00 & 9.25 \\
\hline \multirow{3}{*}{$\mathrm{K}^{+}\left(\operatorname{mmol}_{\mathrm{c}} \mathrm{L}^{-1}\right)$} & Mean \pm SD & $0.11 \pm 0.03 b$ & $0.14 \pm 0.03 \mathrm{a}$ \\
\hline & Min & 0.02 & 0.10 \\
\hline & Max & 0.16 & 0.18 \\
\hline \multirow{3}{*}{$\mathrm{Ca}^{+2}\left(\mathrm{mmol}_{\mathrm{c}} \mathrm{L}^{-1}\right)$} & Mean \pm SD & $2.02 \pm 0.33 \mathrm{~b}$ & $3.73 \pm 0.25 \mathrm{a}$ \\
\hline & Min & 1.32 & 3.28 \\
\hline & Max & 2.59 & 4.01 \\
\hline \multirow{3}{*}{$\mathrm{Mg}^{+2}\left(\mathrm{mmol}_{\mathrm{c}} \mathrm{L}^{-1}\right)$} & Mean \pm SD & $2.08 \pm 0.71 \mathrm{a}$ & $1.95 \pm 0.17 \mathrm{a}$ \\
\hline & Min & 0.71 & 1.66 \\
\hline & Max & 3.53 & 2.15 \\
\hline \multirow{3}{*}{$\mathrm{Cl}^{-}\left(\mathrm{mmol}_{\mathrm{c}} \mathrm{L}^{-1}\right)$} & Mean \pm SD & $6.95 \pm 1.01 \mathrm{a}$ & $2.71 \pm 1.67 \mathrm{~b}$ \\
\hline & Min & 4.55 & 1.10 \\
\hline & Max & 9.19 & 4.60 \\
\hline \multirow{3}{*}{$\mathrm{HCO}_{3}^{-}\left(\mathrm{mmol}_{\mathrm{c}} \mathrm{L}^{-1}\right)$} & Mean \pm SD & $3.36 \pm 0.88 \mathrm{a}$ & $1.49 \pm 0.36 b$ \\
\hline & Min & 1.15 & 0.81 \\
\hline & Max & 4.43 & 1.81 \\
\hline \multirow{3}{*}{$\mathrm{SO}_{4}^{2-}\left(\mathrm{mmol}_{\mathrm{c}} \mathrm{L}^{-1}\right)$} & Mean \pm SD & $0.87 \pm 0.27 \mathrm{a}$ & $0.14 \pm 0.06 \mathrm{~b}$ \\
\hline & Min & 0.23 & 0.05 \\
\hline & Max & 1.22 & 0.19 \\
\hline \multirow{3}{*}{$\mathrm{PO}_{4}^{3-}\left(\mathrm{mg} \mathrm{L}^{-1}\right)$} & Mean \pm SD & $0.37 \pm 0.19 b$ & $4.63 \pm 0.69 \mathrm{a}$ \\
\hline & Min & 0.00 & 4.10 \\
\hline & Max & 0.81 & 5.95 \\
\hline \multirow{3}{*}{$\mathrm{NO}_{3}^{-}\left(\mathrm{mg} \mathrm{L}^{-1}\right)$} & Mean \pm SD & $0.37 \pm 0.61 b$ & $2.41 \pm 0.67 \mathrm{a}$ \\
\hline & Min & 0.00 & 1.58 \\
\hline & Max & 2.55 & 3.06 \\
\hline
\end{tabular}

*Mean values followed by different lowercase letters in a column differ by F-test at a level of $1 \%$ 
as being primarily responsible for the progressive increase in levels of $\mathrm{NO}_{3}^{-}$. Dorigon, Stolberg and Perdomo (2008) associated the high levels of nitrates in the watershed of the Ditinho River, located in Xanxerê in the State of Santa Catarina, with the improper management of animal waste and the intensive agricultural use of the watershed. Changes in land use alter water quality, as discussed by the above-mentioned authors, and confirmed by Vanzela, Hernandez and Franco (2010).

Despite the greater values for $\mathrm{NO}_{3}{ }^{-}$in group 2, the levels are below the standard for potability established by Ordinance 518/2004 of the Ministry of Health, which is $10 \mathrm{mg} \mathrm{L}^{-1}$. It is worth noting that $\mathrm{NO}_{3}^{-}$is a persistent contaminant, highly mobile and not easily degradable in an aerobic environment, and at levels over $10 \mathrm{mg} \mathrm{L}^{-1}$ can cause diseases such as methemoglobinemia and gastric cancer (WHO, 2014). Low concentrations of $\mathrm{NO}_{3}$, below the limit for human consumption, were also seen by Fernandes et al. (2010). With $\mathrm{PO}_{4}{ }^{3-}$, CONAMA Resolution 357/2005 does not establish standards for any form of phosphorus in groundwater, therefore the comparison was developed based on the standards for surface water. Phosphate concentrations in the well water exceeded the limit for class 3 water, established by that resolution $\left(0.15 \mathrm{mg} \mathrm{L}^{-1}\right)$.

\section{CONCLUSIONS}

Groundwater in the perennialised Trussu River valley displayed a greater dynamic over time than the surface water, the main difference between monitoring periods for the groundwater being the values for $\mathrm{EC}, \mathrm{Na}^{+}$, $\mathrm{Cl}^{-}$and $\mathrm{HCO}_{3}^{-}$, that showed significant reductions in the second monitoring period, and an increase of $1,000 \%$ and $500 \%$ in the $\mathrm{PO}_{4}^{3-}$ and $\mathrm{NO}_{3}^{-}$ions respectively. However, the surface waters of the perennialised stretch of the river showed no significant differences in water quality for the two periods of monitoring, demonstrating the resilience of this water resource. For the groundwater, changes in the indicators of water quality between the first and second monitoring period were sharply defined, characterising an alteration in groundwater quality due to the change in land use in the perennialised valley of the Trussu River.

\section{REFERENCES}

AMERICAN PUBLIC HEALTH ASSOCIATION. Standard methods for the examination of water and wastewater. 21 . ed. Washington: American Public Health Association: American Water Works Association: Water Environment Federation, 2005. 1368 p.
ANDRADE, E. M. et al. Land use and ground water quality: the case of Baixo Acaraú Irrigated Perimeter, Brazil. Revista Ciência Agronômica, v. 41, n. 2, p. 208-215, 2010.

ARAÚJO NETO, J. R. et al. Modelagem da estrutura iônica das águas superficiais de reservatórios da bacia Metropolitana do Ceará, Brasil usando regressão linear múltipla. Revista Agro@ mbiente On-line, v. 8, n. 1, p. 1-8, 2014.

ARAÚJO, J. C. de. Recursos hídricos em regiões semiáridas. In: GHEYI, H. R. et al. (Ed). Recursos hídricos em regiões semiáridas: estudos e aplicações. Campina Grande: Instituto Nacional do Semiárido; Cruz das Almas: Universidade Federal do Recôncavo da Bahia, 2012. p. 30-43.

ARAÚJO, P. P. et al. Classificação hidroquímica e contaminação por nitrato no aquífero livre Barreiras na bacia do rio Capitão Pocinho região do médio rio Guamá, na Amazônia oriental. Ambi-Agua, v. 6, n. 2, p. 266-281, 2011.

ARRAES, F. D. D. et al. Identificação dos íons determinantes da condutividade elétrica nas águas superficiais da bacia do Curu, Ceará. Revista Ciência Agronômica, v. 40, n. 3, p. 346355, 2009.

AYERS, R. S.; WESTCOT, D. W. A qualidade da água na agricultura. 2. ed. Campina Grande: UFPB, 1999. 153 p. (FAO. Irrigação e Drenagem, 29).

BARROSO, A. A. F. et al. Avaliação da qualidade da água para irrigação na região Centro Sul no Estado do Ceará. Revista Brasileira de Engenharia Agrícola e Ambiental, v. 15 , n. 6 , p. $588-593,2011$.

COELHO, V. H. R. et al. Dinâmica do uso e ocupação do solo em uma bacia hidrográfica do semiárido brasileiro. Revista Brasileira de Engenharia Agrícola e Ambiental, v. 18, n. 1, p. 64-72, 2014.

DORIGON, E. B.; STOLBERG, J.; PERDOMO, C. C. Qualidade da água em uma microbacia de uso agrícola e urbano em XanxerêSC. Revista de Ciências Ambientais, v. 2, n. 2, p. 105-120, 2008.

FERNANDES, F. B. P. et al. Análise de agrupamento como suporte à gestão qualitativa da água subterrânea no semiárido cearense. Revista Agro@mbiente On-line, v. 4, n. 2, p. 86-95, 2010.

GAlHARTE, C. A.; VIllElA, J. M.; CRESTANA, S. Estimativa da produção de sedimentos em função da mudança de uso e cobertura do solo. Revista Brasileira de Engenharia Agrícola e Ambiental, v. 18, n. 2, 2014.

LOPES, F. B. et al. Assessment of the water quality in a large reservoir in semiarid region of Brazil. Revista Brasileira de Engenharia Agrícola e Ambiental, v. 18, n. 4, p. 437-445, 2014.

LUNA, N. R. S. et al. Dinâmica do nitrato e cloreto no solo e a qualidade das águas subterrâneas do distrito de irrigação Baixo Acaraú, CE. Revista Agro@mbiente On-line, v. 7, n. 1, p. 53-62, 2013.

MEIRELES, A. C. M.; FRISCHKORN, H.; ANDRADE, E. M. Sazonalidade da qualidade das águas do açude Edson Queiroz, 
bacia do Acaraú, no Semiárido cearense. Revista Ciência Agronômica, v. 38, n. 1, p. 25-31, 2007.

PALÁCIO, H. A. Q. et al. Similaridade e fatores determinantes na salinidade das águas superficiais do Ceará, por técnicas multivariadas. Revista Brasileira de Engenharia Agrícola e Ambiental, v. 15, n. 4, p. 395-402, 2011.

PALÁCIO, H. A. Q. Índice de qualidade das águas na parte baixa da bacia hidrográfica do rio Trussu, Ceará. 2004. 96 f. Dissertação (Mestrado em Irrigação e Drenagem) - Universidade Federal do Ceará, Fortaleza, 2004.

SALGADO, E. V. et al. Similaridade das variáveis hidroquímicas com o uso da análise multivariada, na bacia do Salgado, Ceará. Revista Caatinga, v. 24, n. 3, p. 158-166, 2011.

SANTOS, J. C. N. et al. Land use and trophic state dynamics in a tropical semi-arid reservoir. Revista Ciência Agronômica, v. 45 , n. 1 , p. $35-44,2014$.

SILVA, F. K. G. et al. Patterns of species richness and conservation in the Caatinga along elevation algradients in a semiarid ecosystem. Journal of Arid Environments, v. 110, p. 47-52, 2014.
THORNTHWAITE, C. W. An approach toward a rational classification of climate. Geographic Review, v. 38, p. 55-93, 1948.

VANZELA, L. S.; HERNANDEZ, B. T.; FRANCO R. A. M. Influência do uso e ocupação do solo nos recursos hídricos do Córrego Três Barras, Marinópolis. Revista Brasileira de Engenharia Agrícola e Ambiental, v. 14, n. 1, p. 55-64, 2010.

VAROL, M. et al. Spatial and temporal variations in surface water quality of the dam reservoirs in the Tigris River basin, Turkey. Catena, v. 92, p. 11-21, 2012.

WANG, Y. et al. Assessment of surface water quality via multivariate statistical techniques: a case study of the Songhua River Harbin region, China. Journal of Hydro-environment Research, v. 7, p. 30-40, 2013.

WORLD HEALTH ORGANIZATION. Guidelines for drinking-water quality. 2014. Disponível em< http://www. who.int/water_sanitation_health>. Acesso em: 21 abr. 2014.

$\mathrm{XU}, \mathrm{H}$. S. et al. Assessment and spatiotemporal variation analysis of water quality in the Zhangweinan River Basin, China. Procedia Environmental Sciences, v. 13, p. 16411652, 2012. 